\title{
Integrating Russian Methods of Teaching Literature into the World Science and Practice
}

\author{
Tatyana Benkovskaya \\ Department of literature and literature teaching methods, Orenburg State Pedagogical University \\ 460014, Orenburg, Sovetskaya street, 19, Russian Federation \\ E-mail: tbenkovskaya@yandex.ru \\ Zhumagul Maydangalieva (Corresponding author) \\ Department of pedagogy, psychology and subject technologies, S. Baishev Aktyubinsk University \\ 030000, Aktobe, Br. Zhubanovih street, 302a, Republic of Kazakhstan \\ E-mail: maydangalieva@pku.edu.cn
}

Received: 26-07-2016

Published: 02-01-2017
Accepted: 05-10-2016

doi:10.7575/aiac.ijalel.v.6n.1p.286
Advance Access Published: November 2016

URL: http://dx.doi.org/10.7575/aiac.ijalel.v.6n.1p.286

\begin{abstract}
The paper is aimed at solving one of the strategical tasks stated in the Russian literature teaching methods that is associated with its coming into the world science and practice - presentation and dissemination of the Russian experience in the sphere of literary development of school aged readers. The authors are historiographs and proceeding from the results of their research they first suggest considering the possible prospects of completing the task. The first prospect is associated with presentation of the conceptual model of today's Russian methodical system of literary development of schoolchildren in the world science; the second one - with dissemination of the Russian assessment criteria for variative models of the methodical system of literary development of schoolchildren in the world practice. The content of each prospect includes definition of keywords and the technique for implementation of the former. The prospects of presentation and dissemination of the Russian experience in the sphere of literary development of school aged readers that are suggested for implementation can make a considerable contribution to the world experience enriching it with grounded alternative scientific approaches to the assessment of modern condition of literary education in the foreign countries. The authors highlight creation of additional preconditions required for interaction in the area of development of methodology of the comparative science about the reader as one of the important parameter of the successful performance in bringing the prospects into life.
\end{abstract}

Keywords: literary education, reader, structural constituents, conceptual model, variative model

\section{Introduction}

The year of literature in Russia became a starting point for understanding the ways for the Russian methods to come into the world science and practice. Directions for the ways were first proposed and presented to the public in the analytical report on the results of work at the methodological seminar "Problems of methodology of subject techniques and the school education development strategy in the Russian language and literature in the Russian Federation" (literature) (Achkasova et al., 2015).

Within the paper, we are going to discuss the implementation prospects of the first trend proposed - presentation and dissemination of the Russian experience in the sphere of literary development of school aged readers.

Not less important as a motive of presentation and dissemination of the Russian experience in the sphere of literary development of school aged readers in the world science and practice is the celebration of 100 years since birth of the well-known scientist methodologist, Natalia Dmitrievna Moldavskaya (1916-1978). First, it is to N. D. Moldavskaya (1976) that the leading role in working out of the theoretical bases of schoolchildren literary development belongs with good reason. Second, it is with the name of the scientist that the first works on studying the foreign methodical experience of teaching literature are associated. Currently we are witnessing a revival of interest for studying this experience, mostly in the sphere of development of readers. A bright example confirming this is the modern researchers' turning to the content analysis of international published works on reader's development (Borodina, 2009), to studying the correlation between such notions as "literary development of school aged readers" - the Russian model according to V. G. Marantsman (2005) - and "literary competence" - the Western model according to O. Torell (2012)(Yadrovskaya E.R., 2009). 


\section{Literature review}

By the beginning of the XXIst century, the Russian methodical science has amassed the experience of studying the problem of literary development of schoolchildren at various stages of stating and solving that. The statement of the problem of schoolchildren literary development dates back to the point of emergence of literature teaching methodology as a science in the works of outstanding scientists methodologists of the XIXth century (Ostrogskiy, 1885; Stoyunin, 1864). In the late XIXth - early XXth centuries, an important contribution to its working out and solving was made by I. F. Annenskiy (1890), Z. P. Baltalon (1904), V. V. Danilov (1917) and other teachers of the Russian language and literature. The literary development of schoolchildren as a scientific problem was finally established in both theory and and practice of school studying of literature in the 1920-1950s owing to methodical explorations of N. I. Kudryashev (1964), M. A. Rybnikova (1941) and their followers. The broad scientific and research activity of N. D. Moldavskaya (1976) and other scientists methodologists furthered working out of theoretical bases of the problem of literary development of schoolchildren in literature teaching methods of the 1960-1970s. The problem of literary development of schoolchildren becomes the priority one in literature teaching methods of the 1980-2000s. The efforts of scientists methodologists representing the schools of thought created on the bases of chairs of literature teaching methods at A. I. Herzen Russian State Pedagogical University, Moscow State Pedagogical University and the laboratory of literary education of the Institute of General Secondary Education at the Russian Academy of Education were aimed at making the research of the problem of development of school aged readers more extensive and profound.

Today's Russian methodical science has faced the burning issue of generalization of the methodical experience in the sphere of literary development of school aged readers. The first significant results of research into the question obtained by the authors historiographs on the materials covering a two-hundred-year period of development of the methodical science (from the 1840s until the 2000s) can help solving one of the strategical tasks set for the Russian literature teaching methods associated with its coming into the world science and practice - presentation and dissemination of the Russian experience in the sphere of literary development of school aged readers.

\section{Research methods}

The objective of the paper consists in understanding the meaning of the system of literary development of school aged readers created by the Russian methodical science and presentation and dissemination of the Russian methodical experience in the sphere of literary development of school aged readers in the foreign science and practice.

The objective has determined the following research tasks:

1. To generalize the experience of stating the problem of literary development of schoolchildren in literature teaching methodology of the 1840-1950s;

2. To reveal and understand the process of creation and formation of the schoolchildren literary development system in literature teaching methods of the 1960-2000s;

3. To single out and provide grounds for the possible prospects of presentation and dissemination of the Russian methodical experience in the sphere of literary development of school aged readers in the foreign science and practice, as well as of scientific interaction in resolving the problem of upbringing of readers at school.

The methodological bases of the research are as follows:

- the concepts of philosophers that ensure studying of the schoolchildren literary development problem from the standpoint of the all-encompassing connection and mutual conditioning, development and integrity of the phenomena and processes;

- works of literature critics that determine the literature science foundations of statement and solving of the schoolchildren literary development problem - study of the student's personality as of a reader, and taking into account the specific character of literature as the art of word;

- works of pedagogues and psychologists that determine the psychological and pedagogical bases for stating and solving the problem of literary development of schoolchildren - the synergetic ideas about the development of complex systems and education systems;

- the research by scientists methodologists that allow solving the tasks set in this research;

- works of historiographers that provide for studying one of the important historiographical aspects of the schoolchildren literary development problem in the context of the history of development of the methodical science.

In order to solve the research tasks, the following methods were used: historical and bibliographical, systemic method; the analysis of literature science sources and concepts, psychological and pedagogical, didactic, methodical ones; other methods of theoretical analysis (the analysis and synthesis, generalization, comparison, comparative historical method, that of problem analysis, theoretical modeling, ranking); praximetrical methods (analyzing the products of activity of students); prognostic methods (forecasting).

The historical and bibliographical method of task solving required turning to a significant quantity of sources, including the thesis research papers, published works on methodology and adjacent sciences, materials of discussions, congresses 
and meetings of language and literature teachers, scientific conferences, reports by the inspecting agencies about the condition of literature teaching, programs, study books, and materials taken from the experience of work.

\section{Results and discussion}

Within the context of systemic and historical approach to exploring the problem of schoolchildren literary development in literature teaching methodology of the 1840-2000s, we have generalized the Russian experience of stating and solving the problem (Benkovskaya \& Maydangalieva, 2016).

The analysis and generalization of thesis research papers, materials of scientific conferences, papers and monographs has enabled us to reveal and understand the process of creation and formation of the schoolchildren literary development system in the literature teaching methods of the 1840-2000-s, as well as to give grounds for the qualitative and quantitative change of this system.

As a result, in the Russian literature teaching methodology, the following stages of creation and formation of the schoolchildren literary development system were outlined:

- the stage of stating the schoolchildren literary development problem in the literature teaching methods of the 18401950s;

- the stage of creation of the schoolchildren literary development system in the literature teaching methods of the 19601970s;

- the stage of evolution of the system of literary development of schoolchildren in the literature teaching methods of the 19801990s;

- the stage of improvement of the schoolchildren literary development system in the literature teaching methods of the 2000s.

The stage of stating the schoolchildren literary development problem in the literature teaching methods of the 18401950s was completed by revealing the total of key constituents of the problems of literary development of schoolchildren and creating favorable background (conditions) for working out the theoretical bases of the literary development of schoolchildren in literature teaching methodology of the 1960-2000s.

The creation of the schoolchildren literary development system in the literature teaching methods of the 1960-1970s took place as a result of revealing its structural constituents in their interaction as they got grounding within the context of the systemic and historical approach:

- the structural constituents of the process of literary development of schoolchildren,

- the structural constituents of conditions for the successful progress of the schoolchildren literary development process.

The expedience of singling out of the said components follows from the philosophical understanding of the development process as a total of a number of constituents of this process, some of which forming the process, the other ones being conditions for the progress thereof.

Making sense of the philosophical understanding of the development process within the context of the research underlies the representation of the methodical system of literary development of schoolchildren as a total of structural constituents of the schoolchildren literary development process and conditions for the successful progress thereof.

As the structural constituents of the process of literary development of schoolchildren, we hold those structural constituents of the methodical system of literary development of schoolchildren the presence of which indicates the extent of efficiency of implementation of the system.

As for the structural constituents of conditions for the successful progress of the schoolchildren literary development process, here we refer those structural constituents of the methodical system of literary development of schoolchildren the presence of which indicates the extent of efficiency of the system itself.

In particular, we view each of the structural constituents thereof as an open independent system. One or several of them prevailing can be seen in the elaborated by researchers variative models of the methodical system of literary development of schoolchildren.

The stages of evolution and improvement of the schoolchildren literary development system in literature teaching methodology of the 1980-2000s are characterized by qualitative and quantitative change of the system. The change was due to improvement of the existing structural constituents thereof and to revealing of the new ones, as well as to establishing associations between them.

As a result of analysis, at the observations level, the uneven qualitative character of formation of the structural constituents of the schoolchildren literary development process has been revealed in literature teaching methodology at various stages of the 1960-2000s. In philosophy, this phenomenon is characterized as a natural for and characteristic of a complex system undergoing the development process, proceeding from the fact the notion "course of time" is not identical to the " process of development" one. 
Within the paper, we are going to clearly demonstrate the quantitative change of the schoolchildren literary development system in literature teaching methods of the 1980-1990s and 2000s (Table 1).

Relying on the results of generalization of the Russian methodical experience in the sphere of literary development of school aged readers, for a broad scientific discussion, we suggest singling out and considering the prospects of presentation and dissemination of this experience in the world science and practice, in particular:

I. The prospects of presentation of the conceptual model of the contemporary Russian methodical system of literary development of schoolchildren in the world science;

II. The prospects of dissemination of the Russian assessment criteria of the variative models of the methodical system of literary development of schoolchildren in the world practice.

Currently, it is Russian methodical science that has got a conceptual model of the system of literary development of school aged readers which is the only one in the world.

In our research, we proceeded from the generally accepted meaning of the notion "model" that is interpreted in a broad sense as an image, analog (mental or conventional: a picture, description, diagram, drawing, graph, plan, map etc.) of an object, process or phenomenon (the "original" of the model) which is used as a "substitute" or "representative" thereof.

Let us now describe the essence of the notion "conceptual model" in relation to the methodical system of literary development of schoolchildren:

1) the "conceptual model" of the methodical system of literary development of schoolchildren reflects the historical experience of stating and solving the schoolchildren literary development problem;

2) the "conceptual model" of the methodical system of literary development of schoolchildren can be constructed and altered in literature teaching methodology after completing the study of the processes of formation of the schoolchildren literary development system.

In order to visualize the conceptual model of the contemporary Russian methodical system of literary development of schoolchildren in the world science, we suggest looking at its structure (Fig. 1) which was elaborated proceeding from the following:

- The quantity of structural constituents in the methodical system of literary development of schoolchildren (the total of structural constituents is 27 , of them 14 are the structural constituents of the schoolchildren literary development process, and 13 - those of conditions for the successful progress thereof);

- The order of position of the structural constituents of the methodical system of literary development of schoolchildren (according to the time of their getting grounded within the context of systemic and historical approach);

- The character of relations between the structural constituents of the methodical system of literary development of schoolchildren (the "equality" (peer) relation, the "interaction" relation). 
Table 1. The quantitative change of the schoolchildren literary development system in literature teaching methodology of the 1960-2000s

\begin{tabular}{|c|c|c|c|}
\hline Stages & $\begin{array}{l}\text { 1960-1970s: } \\
\text { Creation of the methodical system of } \\
\text { literary development of schoolchildren }\end{array}$ & $\begin{array}{l}1980-1990 s: \\
\text { Evolution of the methodical system of literary } \\
\text { development of schoolchildren }\end{array}$ & $\begin{array}{l}\text { 2000s: } \\
\text { Improvement trends of the methodical system of literary } \\
\text { development of schoolchildren }\end{array}$ \\
\hline 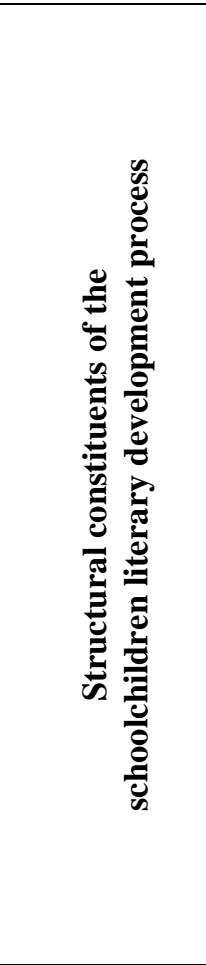 & $\begin{array}{l}\text { The system of development of reader's } \\
\text { perception in schoolchildren; } \\
\text { - The system of development of thinking } \\
\text { in schoolchildren; } \\
\text { - The system of development of } \\
\text { imagination in schoolchildren; } \\
\text { - The system of development of speech in } \\
\text { schoolchildren; } \\
\text { - The system of forming of the literary } \\
\text { knowledge in schoolchildren; } \\
\text { - The system of development of the } \\
\text { schoolchildren's literary abilities; } \\
\text { - The system of development of reader's } \\
\text { interests in schoolchildren; } \\
\text { - The system of development of reader's } \\
\text { independence in schoolchildren. }\end{array}$ & $\begin{array}{l}\text { - The system of development of reader's } \\
\text { perception in schoolchildren; } \\
\text { - The system of development of thinking in } \\
\text { schoolchildren; } \\
\text { - The system of development of imagination in } \\
\text { schoolchildren; } \\
\text { - The system of development of speech in } \\
\text { schoolchildren; } \\
\text { - The system of forming of the literary } \\
\text { knowledge in schoolchildren; } \\
\text { - The system of development of the } \\
\text { schoolchildren's literary abilities; } \\
\text { - The system of development of reader's } \\
\text { interests in schoolchildren; } \\
\text { - The system of development of reader's } \\
\text { independence in schoolchildren; } \\
\text { - The system of emotional development of } \\
\text { schoolchildren; } \\
\text { - The system of development of reader's } \\
\text { culture in schoolchildren; } \\
\text { - The system of development of reader's } \\
\text { activity in schoolchildren. }\end{array}$ & $\begin{array}{l}\text { - The system of development of reader's perception in } \\
\text { schoolchildren; } \\
\text { - The system of development of thinking in schoolchildren; } \\
\text { - The system of development of imagination in } \\
\text { schoolchildren; } \\
\text { - The system of development of speech in schoolchildren; } \\
\text { - The system of forming of the literary knowledge in } \\
\text { schoolchildren; } \\
\text { - The system of development of the schoolchildren's literary } \\
\text { abilities; } \\
\text { - The system of development of reader's interests in } \\
\text { - Theolchildren; } \\
\text { - The system of development of reader's independence in } \\
\text { - The system of development of reader's culture in } \\
\text { - The system of development of reader's activity in } \\
\text { schoolchildren; } \\
\text { - The system of development of reader's consciousness } \\
\text { and self-consciousness in schoolchildren; } \\
\text { - The system of forming the worldview in schoolchildren; } \\
\text { - The system of development of values and meanings } \\
\text { personality sphere in schoolchildren. }\end{array}$ \\
\hline
\end{tabular}




\begin{tabular}{|c|c|c|c|}
\hline 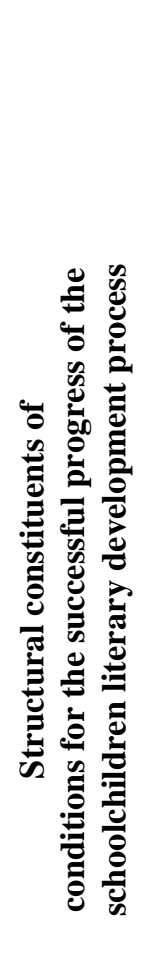 & $\begin{array}{l}\text { The system of connection between class- } \\
\text { based and out-of-school lessons in } \\
\text { literature; } \\
\text { - The system of using the forms of class- } \\
\text { based and out-of-school work in } \\
\text { literature; } \\
\text { - The system of forming the reader's skills } \\
\text { in schoolchildren; } \\
\text { - The system of methods and techniques of } \\
\text { literary development of schoolchildren; } \\
\text { - Consistency of literary development } \\
\text { stages for schoolchildren; } \\
\text { - The system of school analysis of literary } \\
\text { works; } \\
\text { - The system of bringing into life of } \\
\text { intersubject communications at literature } \\
\text { classes; } \\
\text { - The system of creative works, tasks and } \\
\text { exercises in literature; } \\
\text { - The system of literary development } \\
\text { criteria for schoolchildren; } \\
\text { - The system of literary development } \\
\text { research methods for schoolchildren. }\end{array}$ & $\begin{array}{l}\text { The system of connection between class-based } \\
\text { and out-of-school lessons in literature; } \\
\text { - The system of using the forms of class-based } \\
\text { and out-of-school work in literature; } \\
\text { - The system of forming the reader's skills in } \\
\text { schoolchildren; } \\
\text { - The system of methods and techniques of } \\
\text { literary development of schoolchildren; } \\
\text { - Consistency of literary development stages for } \\
\text { schoolchildren; } \\
\text { - The system of school analysis of literary } \\
\text { works; } \\
\text { - The system of bringing into life of intersubject } \\
\text { communications at literature classes; } \\
\text { - The system of creative works, tasks and } \\
\text { exercises in literature; } \\
\text { - The system of literary development criteria for } \\
\text { schoolchildren; } \\
\text { - The system of literary development research } \\
\text { methods for schoolchildren; } \\
\text { - The system of bringing into life of the } \\
\text { connection of literature with other arts. }\end{array}$ & $\begin{array}{l}\text { The system of connection between class-based and out-of- } \\
\text { school lessons in literature; } \\
\text { - The system of using the forms of class-based and out-of- } \\
\text { school work in literature; } \\
\text { - The system of forming the reader's skills in schoolchildren; } \\
\text { - The system of methods and techniques of literary } \\
\text { development of schoolchildren; } \\
\text { - Consistency of literary development stages for } \\
\text { schoolchildren; } \\
\text { - The system of school analysis of literary works; } \\
\text { - The system of bringing into life of intersubject } \\
\text { communications at literature classes; } \\
\text { - The system of creative works, tasks and exercises in } \\
\text { literature; } \\
\text { - The system of literary development criteria for } \\
\text { schoolchildren; } \\
\text { - The system of literary development research methods for } \\
\text { schoolchildren; } \\
\text { - The system of bringing into life of the connection of } \\
\text { literature with other arts; } \\
\text { - The system of bringing into life of the integration } \\
\text { communications at literature classes; } \\
\text { - The system of bringing into life of the intrasubject } \\
\text { communications at literature classes. }\end{array}$ \\
\hline
\end{tabular}

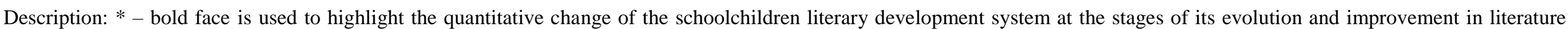
teaching methodology of the 1980-1990s and 2000s.

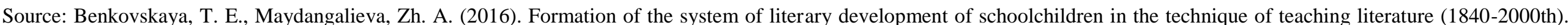
Monografiya. Moscow: Publishing House of the Academy of Natural Sciences, 86-87. 


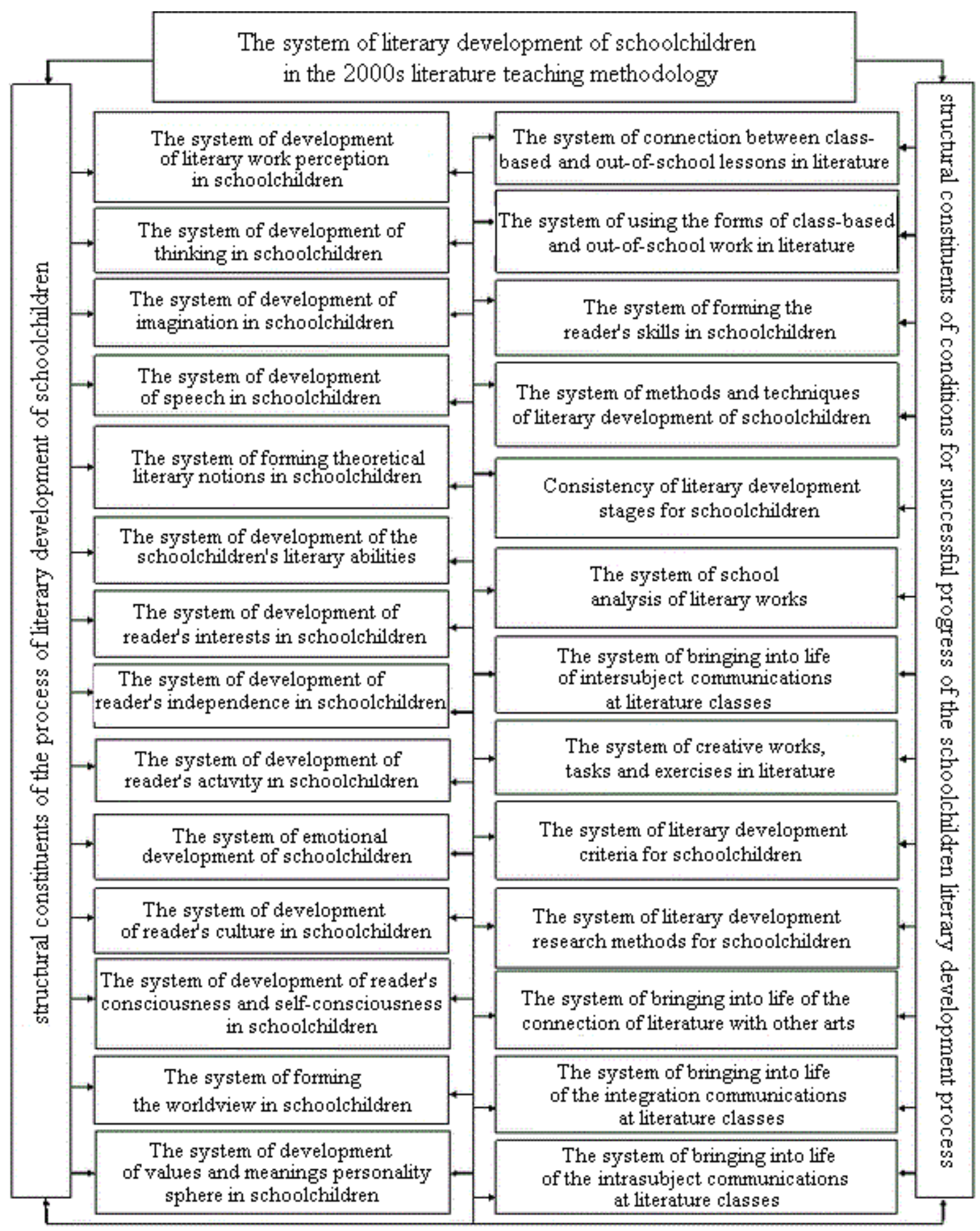

Figure 1. Conceptual model of the contemporary Russian methodical system of literary development of schoolchildren

Source: Benkovskaya, T. E., Maydangalieva, Zh. A. (2016). Formation of the system of literary development of schoolchildren in the technique of teaching literature (1840-2000th). Monografiya. Moscow: Publishing House of the Academy of Natural Sciences, 85.

Let us describe the essence of the notion "variative model" in more detail in relation to the methodical system of literary development of schoolchildren:

1) The "variative model" of the schoolchildren literary development system reflects the author-researcher's (personal) "local" experience;

2) The teachers methodologists' constructing "variative models" of the schoolchildren literary development system precedes their creating a system of work on bringing into life the said models in the literature teaching practice. 
We suggest using the Russian assessment criteria for each of the variative models of the methodical system of literary development of schoolchildren that are contained in the contemporary foreign programs and teaching materials on literature.

The criteria are the presence of completely or partially represented variative models of forming of the structural constituents of conditions for the successful progress of the schoolchildren literary development process (Table 2).

Table 2. Russian assessment criteria of the variative model of methodical system of literary development of schoolchildren

\section{Criteria}

Variative model of the system of connection between class-based and out-of-school

lessons in literature

Variative model of the system of using the forms of class-based and out-of-school work in

literature

Variative model of the system of forming the reader's skills in schoolchildren

Variative model of the system of methods and techniques of literary development of

schoolchildren

Variative model of consistency of literary development stages for schoolchildren

Variative model of the system of school analysis of literary works

Variative model of the system of bringing into life of intersubject communications at

literature classes

Variative model of the system of creative works, tasks and exercises in literature

Variative model of the system of literary development criteria for schoolchildren

Variative model of the system of literary development research methods for

schoolchildren

Variative model of the system of bringing into life of the connection of literature with

other arts

Variative model of the system of bringing into life of the integration communications at

literature classes

Variative model of the system of bringing into life of the intrasubject communications at

literature classes

"+"

"士"

Total ("+" and " $\pm ")$

"-"

Description: "+" - present, " \pm " - partially present, "-" - not available

Source: Benkovskaya, T. E., Maydangalieva, Zh. A. (2016). Formation of the system of literary development of schoolchildren in the technique of teaching literature (1840-2000th). Monografiya. Moscow: Publishing House of the Academy of Natural Sciences, 98.

Results of dissemination and use of these criteria will allow first of all determining the extent of efficiency of the foreign variative models of the methodical system of literary development of schoolchildren, which will lead to an independent and objective ranking thereof thus finding the world's best methodical practices.

The sufficiency of using the criteria suggested is indicated by a regularity found by us which exists in the relation of the extent of efficiency and the extent of efficiency of implementation of each of the variative models of the methodical system of literary development of schoolchildren. The regularity consists in the quality of reading in schoolchildren and their interpretation ability development level (in a broader sense, the extent of efficiency) depending upon the extent of efficiency of the variative model of the schoolchildren literary development system.

In order to determine the regularity, 1123 students took part in the experimental reading quality check, the students being ones of the municipal educational institutions of Orenburg, Orsk and Novotroitsk (Orenburg region) where literature is taught from grade 5 throught grade 11 according to one "line" - using the Russian programs and teaching materials on literature edited by G. I. Belenkiy, Yu. I. Lissiy (2006) V. Ya. Korovina (2009), A. G. Kutuzov (2005), V. G. Marantsman (2005) -for a prolonged time.

The students were offered poetry and prose works, mostly ones not included into the school programs, in order to obtain objective results of reading quality findings in the schoolchildren and their development level of the ability to create interpretation.

We used the technique of checking various spheres of reader's perception (the technology of finding reader's perception in schoolchildren) developed by V. G. Marantsman (2005) that allows judging about the literary development of readers while watching the readers' emotional reactions, work of imagination, understanding of the content and artistic form of the work (Table 3). 
Table 3. The technique for checking various spheres of reader's perception in schoolchildren

$\begin{array}{lll}\text { Emotions } & \text { Understanding of the content } & \text { Reaction to the artistic }\end{array}$

form

1. Expressive reading.

2. Compositions and answers to questions after the first reading of the work. 3. Animated personal impressions and life observations in line with associations with the artistic test.

4. Comparison of the literary text with phenomena of other arts at the emotional assessment level.
1. Making of a plan.

2. Retelling in brief.

3. Commenting on the text.

4. Answers to analytical questions, including ones of a problematic character.

5. Consideration of the composition of the artistic work.

6. Comparison of literary works.

7. Comparison of the works of adjacent arts that are close in topic at the level of concept.
1. Creative retelling (changing the storyteller person).

2. Oral verbal drawing.

3. Drawing up of a cinema script.

4. Staging.

5. Inventing the continuation of the plot.

6. Reconstruction of out-of-scene drama episodes.
1. A close to the text retelling.

2. Stylistic analysis.

3. Justification of imagery words and devices of the author's narration.

4. Comparison of the work and its actual basis.

Source: Benkovskaya, T. E., Maydangalieva, Zh. A. (2016). Formation of the system of literary development of schoolchildren in the technique of teaching literature (1840-2000th). Monografiya. Moscow: Publishing House of the Academy of Natural Sciences, 102.

In line with this technique, we compiled questions and tasks covering various spheres of perception of artistic works (emotional reactions, work of imagination, understanding the content and artistic form of the work) and driving the students to the creation of a reader's interpretation.

As a total, the quality of reading and the interpretation ability development level in schoolchildren were revealed according to the criteria suggested by T. E. Benkovskaya and Zh. A. Maydangalieva (2016) within developed by the methodologist model for assessing the fulfillment level of the unified state examination in literature for the course of main and secondary school (Table 4).

Table 4. The quality of reading and interpretation ability development levels in schoolchildren

\begin{tabular}{|c|c|}
\hline $\begin{array}{l}\text { Quality of reading in } \\
\text { schoolchildren and } \\
\text { interpretation ability } \\
\text { development levels }\end{array}$ & $\begin{array}{c}\text { Criteria of the schoolchildren's quality of reading and } \\
\text { interpretation ability development }\end{array}$ \\
\hline High & $\begin{array}{l}\text { A need for interpreting an artistic work, presenting one's answer in the form of a } \\
\text { coherent and logically laid out text, with one's own standpoint in the interpretation } \\
\text { supported by arguments. } \\
\text { A relevant matching of the reader's and author's emotions, knowing how to enter a } \\
\text { dialogue with the author, to come to the author's concept and to accept it. } \\
\text { The presence of creative imagination, understanding and appraisal of the work at the } \\
\text { level of both content and form, its moral, ethical and esthetical significance. }\end{array}$ \\
\hline Medium & $\begin{array}{l}\text { The ability to give rather detailed answers to questions set and to support one's } \\
\text { standpoint with arguments. } \\
\text { A close matching of the reader's and author's emotions in perceiving the work. } \\
\text { Creative imagination prevails over the reproductive one. } \\
\text { Knowing how to see the proportion of elements in the plot of the work, to trace the } \\
\text { author's idea. Knowing how to see an artistic detail and its function in the text. } \\
\text { Understanding the author's concept. An ability to create one's own interpretation. }\end{array}$ \\
\hline Low & $\begin{array}{l}\text { Inability to answer the questions of the task. } \\
\text { Answering in one word, lack of arguments. } \\
\text { Irrelevant reader's emotions, reproduction of knowledge, unawoken creative } \\
\text { imagination, substitution of the analysis with retelling, failure to understand the } \\
\text { author's concept, inability to correctly assess the work at the levels of the content, } \\
\text { idea, composition, artistic details. Inability to create one's own interpretation of the } \\
\text { work. }\end{array}$ \\
\hline
\end{tabular}

Source: Benkovskaya, T. E., Maydangalieva, Zh. A. (2016). Formation of the system of literary development of schoolchildren in the technique of teaching literature (1840-2000th). Monografiya. Moscow: Publishing House of the Academy of Natural Sciences, 103. 
Thus, it is possible to trace several scientific and practical results firstly obtained in this research study. While N. D. Moldavskaya (1976) gave the first definition of the "schoolchildren literary development" and cleared its criteria and V. G. Marantsman (2005) distincted the periods of literary development of a school aged reader and the changes characterising it at each stage, specified literary development criteria, the authors of this paper for the first time in the Russian methodical literature discourse have revealed the bases for the issue concerning schoolchildren literary development dating back to the 19th - early 20th century when this notion was only mentioned but had not yet entered the terminological system of literary methodology as a science; and they have also firstly traced the emergence and formation of the methodical literary system development in the Russian literature teaching methodology of 1840s-2000, outlined the prospects of its study, convincingly demonstrated its ability to enter the international level.

\section{Conclusion}

Russian science has always closely connected the process of development of personality with the spiritual development. In the methodical tradition, the process of literary education has always been closely associated with that of spiritual and moral upbringing of personality.

The analysis of stating and solving the problem of literary development of a school aged reader in the Russian methodical science throughout its historical path conducted by us has allowed making the following conclusions:

- For the Russian education, literary development is an integral part of general development of a student's personality, of development of his consciousness and literary abilities; it is also a systemic process embracing the entire period of school education and including the development of a reader's and interpretation activity, broadening the cultural outlook and the cultural experience in school aged readers;

- The goal of literary development is "not merely the intellectual mastering, but also emotional acquisition of humanist potential of both art and science, practicing in esthetic and psychological mechanisms of communication between man and art, science, and other people" (Marantsman, 2005);

- Throughout all periods of literary development of a school aged reader, the assessment criteria are levels of development of various sides of reader's perception (emotions, imagination, thinking, attention to the form of a literary work), the reader's analytical and interpretation activity; as well as extensive reading and directed reading;

- The key components of the content of literary development are upbringing of a reader, literary and creative activity of students, broadening of the schoolchildren's cultural field, spiritual and moral upbringing of the students, - which determines the key concepts of literary development: "reader's activity", "creativity", "cultural field", "upbringing";

- In the 2000s methods of teaching literature, the system of literary development of schoolchildren is represented as a total of structural constituents of the process of literary development of schoolchildren and conditions for the successful progress thereof, in particular:

- the structural constituents of the process of literary development of schoolchildren:

- The system of development of reader's perception in schoolchildren;

- The system of development of thinking in schoolchildren;

- The system of development of imagination in schoolchildren;

- The system of development of speech in schoolchildren;

- The system of forming theoretical literary notions in schoolchildren;

- The system of development of the schoolchildren's literary abilities;

- The system of development of reader's interests in schoolchildren;

- The system of development of reader's independence in schoolchildren;

- The system of emotional development of schoolchildren;

- The system of development of reader's culture in schoolchildren;

- The system of development of reader's activity in schoolchildren;

- The system of development of reader's consciousness and self-consciousness in schoolchildren;

- The system of forming the worldview in schoolchildren;

- The system of development of values and meanings personality sphere in schoolchildren;

- the structural constituents of conditions for the successful progress of the schoolchildren literary development process:

- The system of connection between class-based and out-of-school lessons in literature;

- The system of using the forms of class-based and out-of-school work in literature;

- The system of forming the reader's skills in schoolchildren;

- The system of methods and techniques of literary development of schoolchildren;

- Consistency of literary development stages for schoolchildren;

- The system of school analysis of literary works;

- The system of bringing into life of intersubject communications at literature classes; 
- The system of creative works, tasks and exercises in literature;

- The system of literary development criteria for schoolchildren;

- The system of literary development research methods for schoolchildren;

- The system of bringing into life of the connection of literature with other arts;

- The system of bringing into life of the integration communications at literature classes;

- The system of bringing into life of the intrasubject communications at literature classes.

The essence of notions "conceptual model" and "variative model" in relation to the methodical system of literary development of schoolchildren can be described by two aspects:

1) The "conceptual" model of schoolchildren literary development system reflects the historical experience of solving the problem of schoolchildren literary development; meanwhile, the "variative" models of schoolchildren literary development system reflect (personal) "local" experience of the authors-researchers;

2) Construction of the "conceptual model" of schoolchildren literary development system becomes possible in the 2000s methods of teaching literature after completing the research into processes of establishing of the schoolchildren literary development system (the 1960-1970s), its evolution (the 1980-1990s) and improvement (the 2000s); as for teachers methodologists' constructing the "variative models" of schoolchildren literary development system, it precedes their creating a system of work on implementation of the models into literature teaching practice;

The quality of reading in schoolchildren and their level of development of the ability for creating an interpretation depend on the extent of efficiency of the variative model of schoolchildren literary development system that is designed in the program and the teaching materials on literature.

Thus, our statement of the strategic task of introducing the Russian methods into the world science and practice gives evidence for the contemporary science about school aged readers has got all the resources required for completing the task. The prospects of presentation and dissemination of the Russian experience in developing school aged readers are a confirmation of this, in particular:

I. The prospects of presentation of the conceptual model of today's Russian methodical system of literary development of schoolchildren in the world science;

II. The prospects of dissemination of the Russian assessment criteria for variative models of the methodical schoolchildren literary development system in the world practice.

The content of each prospect includes definition of keywords and the technique for its bringing into life. The objective character of their content in the paper is based on the results of historiographical and empirical research of the problem of literary development of schoolchildren, and it is also confirmed by the official inclusion into the glossary of the author's definition of the methodical schoolchildren literary development system and introduction of key notions ("conceptual model of literary development system", "structural constituents of literary development process") into the terminology of the contemporary Russian methodical science about school aged readers (Domanskiy V.A. et al., 2015).

\section{References}

Achkasova, G. L. et. al. (2015). Analytical report on the results of the methodological seminar "Problems of methodology of subject methods and strategies for the development of school education in the Russian language and literature in the Russian Federation" (literature). Open method: search - research - creativity: proceedings on the methods of teaching the Russian language and literature. St. Petersburg: «Own publishing house», 86.

Annenskiy, I. F. (1890). Educational value of the native language. Russian school, 1, 21-44.

Baltalon, Ts. P. (1904). Methodical manualfor literary conversations and written work. 5th edition. Moscow: printing house of A.I. Mammoth partnership, XIV + 201p.

Benkovskaya, T. E., Maydangalieva, Zh. A. (2016). Formation of the system of literary development of schoolchildren in the technique of teaching literature (1840-2000th). Monografiya. Moscow: Publishing House of the Academy of Natural Sciences, 141 p.

Borodin, V. A. (2009). Aspect after aspect and content analysis in the study of reader's development (on the materials of the journal «READING RESEARCH QUARTERLY», 2004-2007). Bibliosphere, 2, 3-13.

Danilov, V. V. (1917). Literature as a subject of teaching. Moscow: printing house of I. D. Sytin partnership, 176 p.

Domanskiy, V. A. et. al. (2015). Literary development of school aged reader. Glossary of methodical terms and concepts (Russian language, literature): Experience of building terminological system. Edited by E. R. Yadrovskaya, A. I. Dunev. SPb: «Own publishing house», 209, 316, 320.

In the world of literature. Grades 5-11: program in literature for educational institutions (2005). Edited by A. G. Kutuzov. Moscow: Bustard, 79 p.

Kudryashev, N. I. (1964). Training and development. Literature at school, 2, 3-9.

Literary education program (grades 5-9) (2005). Edited by V. G. Marantsman. Moscow: Education, 222 p.

Moldavskaya, N. D. (1976). Literary development of schoolchildren in the learning process. Moscow: Pedagogy, 224 p. 
Ostrogorskiy, V. (1885). Talking about literature teaching. Moscow: Demakov`s printing house, $111 \mathrm{p}$.

Program of educational institutions: Literature (2006). Grades 5-11. Edited by G. I Belenkiy, Yu. I. Lyssiy. Moscow: Mnemosyne, $141 \mathrm{p}$.

Program of educational institutions: Literature. Grades 5-11 (Basic level). 10-11 (Profile level) (2009). Edited by V. Ja. Korovina. 11th edition. Moscow: Education, 255 p.

Rybnikov, M. A. (1941). Essays on the methodology of literary reading. Moscow: Uchpedgiz, 277 p.

Stoyunin, V. Ya. (1864). About Russian literature teaching. St. Petersburg: printing house Paulson \& Co., 392 p.

Torell, O. (2012). About literary competence and checking «literacy» in the project «PISA». Modern philological education: a collection of articles of the II International pedagogical seminar (St. Petersburg, 2012). St. Petersburg: «Book House» Ltd., 2012, 12-19.

Yadrovskaya, E. R. (2009). Analysis and correlation of the concepts of "schoolchildren literary development", "literary competence", "reading competence". World of Science, Culture and Education, 5(17), 132-139. 